\title{
Corticothalamic Inputs Control the Pattern of Activity Generated in Thalamocortical Networks
}

\author{
Hal Blumenfeld ${ }^{1,2}$ and David A. McCormick ${ }^{1}$ \\ ${ }^{1}$ Section of Neurobiology and 2Department of Neurology, Yale University School of Medicine, New Haven, \\ Connecticut 06520
}

\begin{abstract}
Absence seizures (3-4 Hz) and sleep spindles (6-14 Hz) occur mostly during slow-wave sleep and have been hypothesized to involve the same corticothalamic network. However, the mechanism by which this network transforms from one form of activity to the other is not well understood. Here we examine this question using ferret lateral geniculate nucleus slices and stimulation of the corticothalamic tract. A feedback circuit, meant to mimic the cortical influence in vivo, was arranged such that thalamic burst firing resulted in stimulation of the corticothalamic tract. Stimuli were either single shocks to mimic normal action potential firing by cortical neurons or highfrequency bursts (six shocks at $200 \mathrm{~Hz}$ ) to simulate increased cortical firing, such as during seizures. With one corticothalamic stimulus per thalamic burst, $6-10 \mathrm{~Hz}$ oscillations resembling spindle waves were generated. However, if the stimulation was a burst, the network immediately transformed into a $3-4 \mathrm{~Hz}$
\end{abstract}

Cortical and thalamic networks interact to generate a variety of normal and abnormal rhythmic states. These states include spindle waves and absence seizures. Spindle waves are characterized by $1-4$ sec periods of $6-14 \mathrm{~Hz}$ oscillation during normal sleep (Steriade et al., 1993). Absence seizures occur most commonly in young children as staring spells lasting 5-10 sec, accompanied by a massive 3-4 Hz rhythmic discharge in the EEG (Niedermeyer, 1990). Sleep spindles and absence seizures may be related phenomena, as evidenced by their occurrence in the same corticothalamic network and, most commonly, during the same stages of sleep (Kellaway, 1985; Niedermeyer, 1993). How does the same corticothalamic network that generates $6-14 \mathrm{~Hz}$ spindle waves switch to 3-4 Hz spike-wave activity as seen in absence seizures?

Evidence from in vivo animal models suggests that network interactions involving both cortex and thalamus are important for this transition (Avoli et al., 1983, 1990; Danober et al., 1998). The transition to spike-wave seizures is accompanied by a large increase in firing of cortical neurons during the spike component in comparison with the activity associated with spindle waves (Kostopoulos et al., 1981; Avoli and Kostopoulos, 1982; McLachlan et al., 1984; see also Steriade and Contreras, 1995; Kandel and Buzsaki, 1997; Steriade et al., 1998). Furthermore, in the feline

\footnotetext{
Received Feb. 28, 2000; revised April 7, 2000; accepted April 13, 2000.

This work was supported by National Institutes of Health Grants NS 02060 to H.B. and NS 26143 to D.A.M. and by a Pfizer postdoctoral fellowship to H.B. CGP 35348 was generously provided by Novartis. We thank Drs. Joshua Brumberg, Anita Luthi, and Uhnoh Kim for helpful discussions and comments on this manuscript.

Correspondence should be addressed to Dr. Hal Blumenfeld, Yale University School of Medicine, Neurobiology, 333 Cedar Street, New Haven, CT 06520. E-mail: hal.blumenfeld@yale.edu.

Copyright (C) 2000 Society for Neuroscience $\quad 0270-6474 / 00 / 205153-10 \$ 15.00 / 0$
}

paroxysmal oscillation. This transition was associated with a strong increase in the burst firing of GABAergic perigeniculate neurons. In addition, thalamocortical neurons showed a transition from fast (100-150 msec) IPSPs to slow ( $200 \mathrm{msec})$

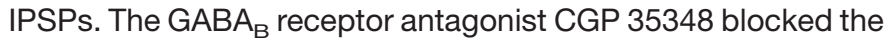
slow IPSPs and converted the 3-4 $\mathrm{Hz}$ paroxysmal oscillations back to $6-10 \mathrm{~Hz}$ spindle waves. Conversely, the GABA $\mathrm{A}_{\mathrm{A}}$ receptor antagonist picrotoxin blocked spindle frequency oscillations resulting in 3-4 $\mathrm{Hz}$ oscillations with either single or burst stimuli. We suggest that differential activation of thalamic $\mathrm{GABA}_{A}$ and $\mathrm{GABA}_{B}$ receptors in response to varying corticothalamic input patterns may be critical in setting the oscillation frequency of thalamocortical network interactions.

Key words: GABA; corticothalamic; thalamocortical; absence seizures; petit mal; sleep spindles; epilepsy; sleep; networks generalized penicillin epilepsy model, increased cortical excitability by application of the weak $\mathrm{GABA}_{\mathrm{A}}$ antagonist penicillin to the cortex without application to the thalamus is sufficient to cause a transition to spike-wave seizures (Avoli and Gloor, 1982), and computational models of spike-wave generation suggest that cortical disinhibition may result in low-frequency thalamocortical oscillations (Destexhe, 1998; Destexhe et al., 1999). How does enhanced cortical firing influence the thalamus to transform the network to $3-4 \mathrm{~Hz}$ paroxysmal activity?

In previous work, the cellular elements of thalamic networks involved in both sleep spindles and slow 3-4 Hz oscillations have been studied in detail (Steriade et al., 1993, 1997; McCormick and Bal, 1997). Spindle waves are generated as a reciprocal interaction between excitatory thalamocortical cells and inhibitory GABAergic thalamic reticular or perigeniculate $(\mathrm{PGN})$ cells and depend on fast $(100-150 \mathrm{msec}) \mathrm{GABA}_{\mathrm{A}}$ receptor-mediated IPSPs in thalamocortical cells to set the network oscillation frequency at 6-14 Hz. Spontaneous 3-4 Hz activity, resembling in some respects that seen with absence seizures, can be generated in the isolated lateral geniculate nucleus (LGN) thalamic slice by the block of $\mathrm{GABA}_{\mathrm{A}}$ receptors, apparently because of the generation of large sustained bursts of action potentials in the GABAergic PGN cells. Dual intracellular recordings from PGN cells synaptically coupled to thalamocortical cells showed that strong burst firing in PGN cells can activate slow ( $2300 \mathrm{msec}) \mathrm{GABA}_{\mathrm{B}}$ receptor-mediated IPSPs in thalamocortical cells, setting the network oscillation frequency to 3-4 Hz. Brief bursts of action potentials in PGN cells, on the other hand, primarily activate fast

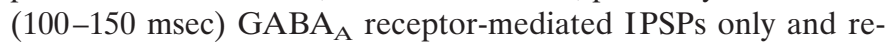
sult in the generation of spindle waves (Kim et al., 1997). 


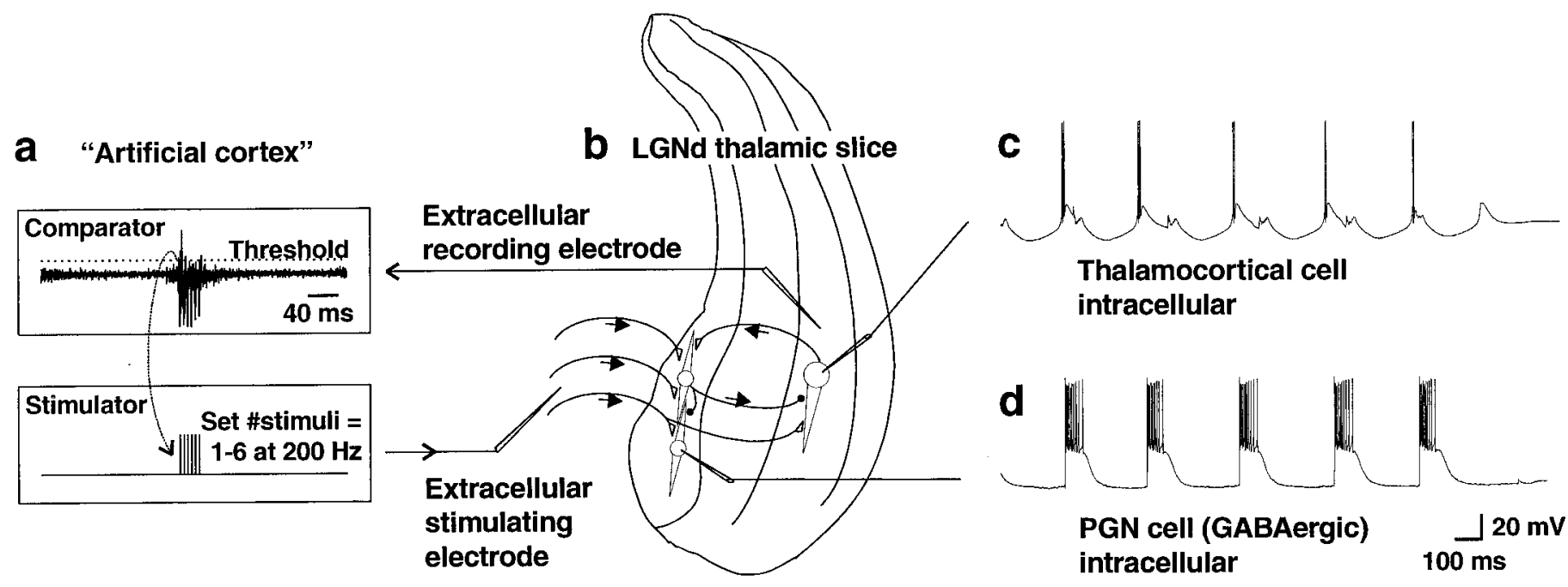

Figure 1. Artificial cortex circuit. $a$, The artificial cortex consisted of a threshold comparator and a stimulator. The threshold of the comparator was adjusted to be triggered by multiunit activity in the A laminae of the LGNd. The threshold was adjusted such that this stimulation unit was usually only activated by bursts of activity in the LGNd. After being triggered, the stimulator remained refractory for 80 msec. The stimulator was set to deliver either single stimuli $(0.1 \mathrm{msec} ; 30-200 \mu \mathrm{A})$ or brief $200 \mathrm{~Hz}$ bursts of six stimuli to the optic radiation. $b$, A drawing of the placement of recording and stimulating electrodes is shown. $c, d$, Intracellular recordings were obtained from thalamocortical cells $(c)$ or from GABAergic PGN cells $(d)$. Recordings shown are with the stimulator set to deliver six corticothalamic stimuli per thalamic burst, producing sustained PGN cell (GABAergic) firing, slow $\mathrm{GABA}_{\mathrm{B}}$-mediated thalamocortical cell IPSPs, and large rebound bursts in thalamocortical cells, resulting in spontaneous 3-4 $\mathrm{Hz}$ oscillations.

We hypothesize that increased cortical firing may cause increased firing of GABAergic PGN cells leading to enhanced $\mathrm{GABA}_{\mathrm{B}}$ receptor activation in thalamocortical cells, ultimately triggering a transformation from spindle waves to $3-4 \mathrm{~Hz}$ spikewave seizures, and we have tested this hypothesis using feedback electrical stimulation of the corticothalamic tract in geniculate slices.

Parts of this paper have been published previously in abstract form (Blumenfeld and McCormick, 1999).

\section{MATERIALS AND METHODS}

Recording and stimulating configuration. Slices of the ferret dorsal LGN (LGNd) preserve the circuitry needed to generate both spontaneous 6-10 Hz spindle waves and 3-4 Hz slow oscillations (Bal et al., 1995a,b; Kim et al., 1997; McCormick and Bal, 1997). The influence of corticothalamic input patterns on this network was investigated using the configuration shown in Figure 1. Intracellular recordings were performed either from the GABAergic PGN cells or from thalamocortical cells in the A or A1 laminae. Extracellular multiunit recordings were obtained immediately adjacent to the thalamocortical cell intracellular electrode (when one was present) and bandpass filtered between $\sim 300$ and 10,000 Hz. The thalamic multiunit activity, representing thalamic output, was fed into an "artificial cortex" circuit interposed between thalamic output and input (Fig. 1a). The artificial cortex consisted of a comparator and a stimulator. When thalamic extracellular multiunit activity exceeded the threshold of the comparator, a trigger pulse was passed to the stimulator. The stimulator then delivered electrical stimuli to the optic radiation, which contains the corticothalamic fibers, after a short adjustable delay $(0-50 \mathrm{msec})$, in the range of fast thalamocortical conduction latencies (Swadlow and Weyand, 1987; Nowak and Bullier, 1997; Timofeev et al., 1998). The extracellular stimulating electrode was placed in the optic radiation $\sim 1-2 \mathrm{~mm}$ away from the PGN (Fig. 1b). The stimulator (Master-8; A.M.P.I., Jerusalem, Israel) was set either to deliver a single $0.1 \mathrm{msec}$ pulse $(30-200 \mu \mathrm{A})$ to simulate a low or normal level of cortical firing or to deliver a brief $200 \mathrm{~Hz}$ train of six stimuli, which was meant to simulate a burst of activity in cortical networks of the kind seen during seizure activity (Fisher and Prince, 1977; van Brederode and Snyder, 1992). Because the duration of thalamic bursts was up to $\sim 80 \mathrm{msec}$, the stimulator was set so that it would remain refractory for a period of 80 msec after generating a pulse (or train) to minimize double triggering of the stimulator during a single thalamic burst. This resulted in a maximal allowable spontaneous oscillation frequency of $1000 /(80)=12.5 \mathrm{~Hz}$.
During setup, the position of the stimulating electrode, the stimulus strength, and the threshold level of the artificial cortex were adjusted until spontaneous 3-4 Hz oscillations were obtained with $200 \mathrm{~Hz}$ trains of six stimuli. Although single spikes could trigger the stimulator, stimulation was typically triggered only by bursts of action potentials, because most neurons in the LGNd slice are silent in between the generation of spindle waves and the probability of cells that generate the largest action potentials (e.g., the few cells close to the electrode) spontaneously discharging in between spindle waves is low (Bal et al., 1995a,b). After the stimulation parameters were achieved that were reliably activated by burst firing in the multiple unit recording and generated strong feedback to the local thalamic circuit, electrode position, stimulus strength, and threshold level were kept fixed for the remainder of the experiment. Although the extracellular stimulating electrode was placed in the optic radiation, antidromic spikes in thalamocortical cells were rarely seen, indicating that the excitation of PGN neurons resulted primarily from activation of corticothalamic fibers. When antidromic spikes were observed, the stimulating electrode was repositioned, and the stimulus intensity was reduced until antidromic spikes were eliminated.

Slice preparation. Male or female 2- to 3-month-old ferrets were deeply anesthetized with sodium pentobarbital $(30 \mathrm{mg} / \mathrm{kg}$, i.p. $)$ and killed by decapitation. The brain was rapidly removed and placed into a chilled aerated solution in which $\mathrm{NaCl}$ was replaced with sucrose while an osmolarity of 307 mOsm was maintained (Aghajanian and Rasmussen, 1989). This sucrose-substituted solution was used during the remainder of the slice preparation procedure to improve tissue viability. The hemispheres were separated with a midline incision. A vibratome (DSK microslicer; Ted Pella, Irvine, CA) was used to obtain sagittal slices (400 $\mu \mathrm{m}$ thick) of the lateral geniculate nucleus. Slices were then transferred to an interface-style recording chamber (Fine Science Tools, North Vancouver, British Columbia, Canada) and allowed at least $2 \mathrm{hr}$ to recover before recordings. The perfusion medium was an artificial CSF (ACSF) containing (in $\mathrm{mm}$ ): $\mathrm{NaCl} 126, \mathrm{KCl} 2.5, \mathrm{MgSO}_{4} 1.2$ or 2.0, $\mathrm{NaH}_{2} \mathrm{PO}_{4} 1.25, \mathrm{CaCl}_{2} 2, \mathrm{NaHCO}_{3} 26$, and dextrose 10 , aerated with $95 \%$ $\mathrm{O}_{2}$ and $5 \% \mathrm{CO}_{2}$ to a final $\mathrm{pH}$ of 7.4. For the first 20 min that the slices were in the recording chamber, the medium contained an equal mixture of $2.0 \mathrm{~mm} \mathrm{MgSO}_{4} \mathrm{ACSF}$ and the sucrose-substituted solution. For the next $60 \mathrm{~min}$, the slices were perfused with $2.0 \mathrm{~mm} \mathrm{MgSO}_{4} \mathrm{ACSF}$. The solution was then changed to ACSF with $1.2 \mathrm{~mm} \mathrm{MgSO}_{4}$ for the remainder of the experiment. Bath temperature was maintained at $34-35^{\circ} \mathrm{C}$. Only slices that generated spontaneous spindle-wave oscillations were used for these experiments.

Microelectrodes. Intracellular recording electrodes were pulled using medium-walled glass (1BF 100; World Precision Instruments, Sarasota, 


\section{Thalamocortical Cell}

\section{a Spontaneous Spindle Wave LGN extracellular}

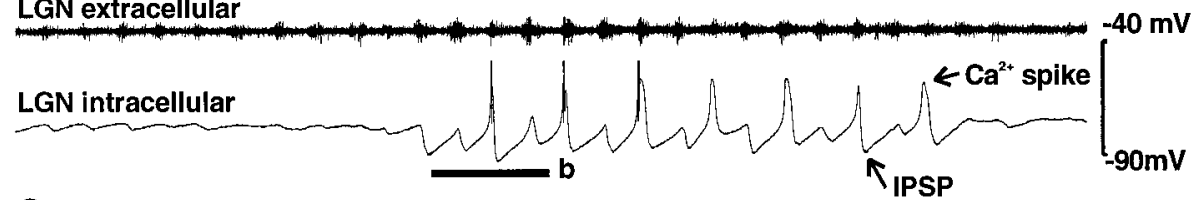

C Shock Once per Cycle

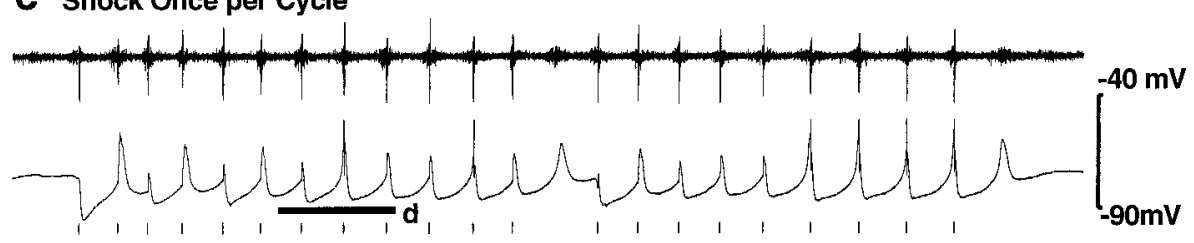

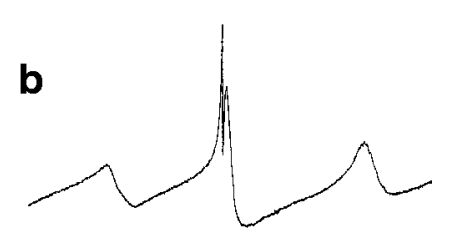

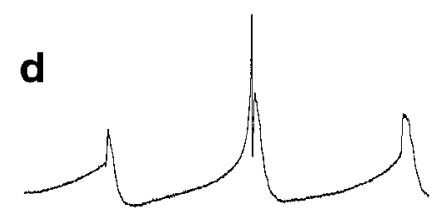

\section{e Shock Six Times per Cycle}

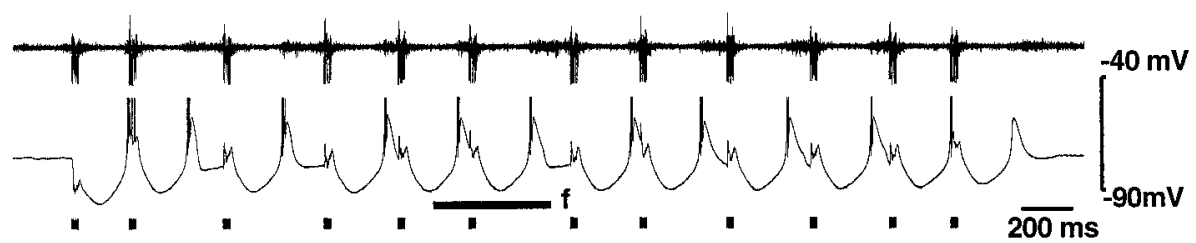

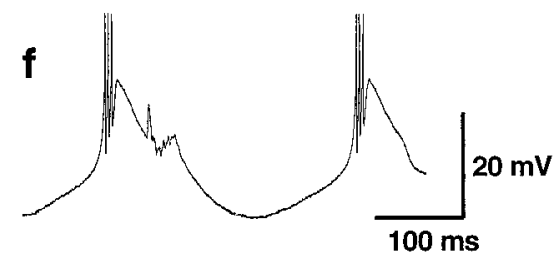

Figure 2. Single corticothalamic stimuli elicit $6-10 \mathrm{~Hz}$ spindle waves, whereas high-frequency bursts of six stimuli elicit 3-4 $\mathrm{Hz}$ oscillations. a, A recording of a spontaneous spindle wave with the LGN extracellular electrode (top trace) demonstrates waxing and waning bursts of multiunit activity at $6-10 \mathrm{~Hz}$. An intracellular recording from a thalamocortical cell (bottom trace) demonstrates rhythmic fast (100-150 msec) IPSPs with rebound Ca ${ }^{2+}$ spikes that occasionally generate action potentials. Action potentials are clipped at this magnification. $b$, An expanded trace of the intracellular recording in $a$ from the portion indicated by the thick horizontal line is shown. $c$, With the stimulation of the corticothalamic tract once per activation, the network generated spontaneous oscillations that resemble spindle waves in both frequency and IPSP shape, although they were typically longer in duration. Extracellular recordings (top trace) demonstrate both multiunit activity and a larger field potential evoked by the stimulus. Stimulus pulses are represented by tick marks (or ovals; see Fig. 3) below the traces in this and all other figures. Stimulus artifacts were removed manually from this and all other recordings illustrated. $d$, An expanded trace of the intracellular recording in $c$ (bottom trace) from the portion indicated by the thick horizontal line is shown. $e$, With the stimulator set to deliver $200 \mathrm{~Hz}$ bursts of six stimuli for each thalamic burst, the network transforms to $3-4 \mathrm{~Hz}$ activity, with slow $(\sim 300 \mathrm{msec})$ IPSPs and increased rebound burst firing. The discharge of various single neurons intracellularly recorded (bottom trace) occurred at different times in relationship to the multiunit extracellular burst (top trace). Thus, the thalamocortical cell recorded here fired relatively early in the burst, whereas the thalamocortical cell shown below (see Fig. 5) fired later in the burst. f, An expanded trace of the intracellular recording in $e$ from the portion indicated by the thick horizontal line is shown.

FL) on a Sutter Instruments P-80 micropipette puller (Novato, CA). Microelectrodes were filled with $1.2 \mathrm{M} \mathrm{K}$-acetate and beveled to a final resistance of 60-120 M 2 . Extracellular multiunit recordings were obtained with low-resistance $(<1 \mathrm{M} \Omega)$ tungsten microelectrodes (Fredrick Haer Corporation, Bowdoinham, ME). Electrical stimulation (30-200 $\mu \mathrm{A} ; 0.1$ msec duration) was performed using a constant-current generator (World Precision Instruments) and passed through a concentric bipolar stimulating electrode (Fredrick Haer Corporation).

Drug application. CGP 35348 (Novartis, Basel, Switzerland) or picrotoxin (Sigma, St. Louis, MO) was added either by bath perfusion (200 $\mu \mathrm{M}$ CGP 35348 or $100 \mu \mathrm{M}$ picrotoxin) or puffer pipette ( 2 mM CGP 35348 or $1 \mathrm{~mm}$ picrotoxin in the pipette) in which a brief pulse of pressurized $\mathrm{N}_{2}$ (10-250 msec; 200-350 kPa) was applied to the back of a broken microelectrode (1-4 $\mu \mathrm{m}$ tip diameter) to extrude an $\sim 1-20 \mathrm{pl}$ droplet of solution. In all experiments in which drugs were applied, baseline control data were first obtained (see Fig. $7 b$ ). Oscillation measurements were then repeated $30 \mathrm{~min}$ after changing the bath perfusion or immediately after drug application by puffer pipette.

\section{RESULTS}

\section{Corticothalamic input pattern determines thalamocortical oscillation frequency}

Slices of the ferret dorsal LGN preserve the circuitry needed to generate both $6-10 \mathrm{~Hz}$ spindle waves and 3-4 Hz slow oscillations (Bal et al., 1995a,b; Kim et al., 1997; McCormick and Bal, 1997). To test the role of corticothalamic inputs in generating these two distinct rhythms, feedback stimulation of corticothalamic fibers was used (Fig. 1) with either single $0.1 \mathrm{msec}$ shocks to mimic normal cortical firing or brief bursts of six shocks at $200 \mathrm{~Hz}$ to mimic abnormally enhanced cortical excitability (Fisher and Prince, 1977; van Brederode and Snyder, 1992).

Spontaneous spindle waves occurred in LGN thalamic slices with an intrinsic frequency of $6-10 \mathrm{~Hz}$ as described previously (Bal et al., 1995a,b). Intracellular recordings from thalamocortical cells during these events (Fig. 2a,b) exhibited rhythmic alternating IPSPs and low-threshold calcium spikes crowned by occasional action potentials. IPSPs had a mean duration of $167 \pm 4.6$ msec $( \pm \operatorname{SEM} ; n=16)$, resulting in a mean oscillation frequency of $6.05 \pm 0.15 \mathrm{~Hz}(n=16)$. The total duration of each spindle wave was $3-10 \mathrm{sec}(4.49 \pm 0.46 \mathrm{sec} ; n=16)$, and these events spontaneously recurred every $20-30 \mathrm{sec}$, with a relatively quiescent period intervening between each spindle. When the artificial cortex was added to the circuit and set to deliver one stimulus each time it was triggered by thalamocortical activity, spontaneous oscillations occurred as well, often initiated by the onset of a spindle wave (Fig. 2c). These resembled spindle waves in oscillation frequency $(6.4 \pm 0.15 \mathrm{~Hz} ; n=16)$ and in IPSP shape and duration (157 $\pm 4.2 \mathrm{msec} ; n=16)$ (Fig. $2 d)$. Network oscillations generated with single-shock stimuli were slightly longer in total duration $(8.85 \pm 1.42 \mathrm{sec} ; n=16 ; p<0.01$, two-tailed $t$ test $)$ and were followed by a small slow afterdepolarization, as seen in normal spindles (Bal and McCormick, 1996). When the electrical 
stimulator was instead set to deliver a burst of six stimuli in response to thalamocortical activity, there was a marked transformation of the network activity (Fig. $2 e$ ) to a $3-4 \mathrm{~Hz}(3.32 \pm$ $0.12 \mathrm{~Hz} ; n=16 ; p<0.0001$, two-tailed $t$ test) event. The mean IPSP duration in thalamocortical cells increased to $307 \pm 10 \mathrm{msec}$ ( $\pm \mathrm{SEM} ; n=16 ; p<0.0001$, two-tailed $t$ test), and stronger rebound bursts of three or more action potentials occurred in these cells with each cycle (Fig. $2 f$ ). These changes were observed in extracellular recordings from 49 ferret LGN slices and in intracellular recordings from 34 thalamocortical cells. Quantitative analysis was performed on 16 of these experiments in which drugs were applied (see Fig. $7 b$ below).

Oscillations terminated when a burst occurred in the thalamic slice that was below the threshold of the comparator (Figs. 1a, $2 c, e)$. Mean oscillation frequency was somewhat higher at the beginning of each event $(7.18 \pm 0.22 \mathrm{~Hz}$, one shock; $3.65 \pm 0.13$ $\mathrm{Hz}$, six shocks) than at the end $(5.82 \pm 0.18 \mathrm{~Hz}$, one shock; $3.05 \pm$ $0.12 \mathrm{~Hz}$, six shocks; $n=16 ; p<0.0001$ and $<0.005$ for one and six shocks, respectively, two-tailed $t$ test).

\section{Lengthening of the IPSPs from short to long duration is mediated by an increased duration of spike bursts in GABAergic neurons}

As discussed above, thalamocortical cell IPSPs were of significantly shorter duration in response to single versus burst stimulation, presumably because of differences in GABAergic cell activity (Kim et al., 1997). To test this hypothesis, we performed intracellular recordings from the GABAergic PGN cells during the different stimulation protocols. During spontaneous spindle waves, PGN cells exhibited rhythmic EPSPs and low-threshold calcium spikes at $6-10 \mathrm{~Hz}$ with superimposed burst firing (Fig. $3 a, d)$ of approximately three to five action potentials per cycle, as reported previously (Bal et al., 1995a,b). When the corticothalamic tract was stimulated once per thalamic burst, the oscillation frequency, PSP pattern, and burst firing were similar to that seen during spindles (Fig. 3b,e). With six stimuli per burst, the oscillation frequency immediately slowed to $3-4 \mathrm{~Hz}$ as discussed above (Fig. 3c). In addition, there was a marked increase in PGN cell burst firing of $12-15$ action potentials per cycle (Fig. $3 f ; n=$ 8 ). These findings suggest that normal brief corticothalamic firing causes brief action potential bursts in PGN cells resulting in fast IPSPs in thalamocortical cells, presumably via $\mathrm{GABA}_{\mathrm{A}}$ receptors, whereas more intense corticothalamic firing causes sustained action potential bursts in PGN cells resulting in slow IPSPs in thalamocortical cells, possibly mediated by $\mathrm{GABA}_{\mathrm{B}}$ receptors.

\section{$\mathrm{GABA}_{\mathrm{B}}$ receptor antagonist blocks both slow IPSPs and slow 3-4 Hz oscillations}

To investigate the role of $\mathrm{GABA}_{\mathrm{B}}$ receptors in the transition from 6-10 to 3-4 Hz spontaneous oscillations, we used the $\mathrm{GABA}_{\mathrm{B}}$ antagonist CGP 35348. Under normal conditions, one corticothalamic shock per cycle produced $6-10 \mathrm{~Hz}$ oscillations with fast IPSPs recorded from thalamocortical cells (see Figs. 4a, 5a, 7b), whereas six stimuli per cycle caused a transition to $3-4 \mathrm{~Hz}$ oscillations with slow IPSPs (see Figs. $4 b, 5 b, 7 b$ ). However, application of the GABA $_{\mathrm{B}}$ antagonist CGP $35348(200 \mu \mathrm{M}$ bath application or $2 \mathrm{mM}$ in the puffer pipette) blocked this transition (see Figs. $4 c, d, 5 d-f, 7 b$ ). Thus, in the presence of CGP 35348, both one and six shocks per cycle resulted in a similar oscillation frequency of $6-10 \mathrm{~Hz}$ [see Fig. $7 b ; 7.17 \pm 0.23 \mathrm{~Hz}(n=10)$, one shock; $6.72 \pm 0.28 \mathrm{~Hz}(n=11)$, six shocks; $p=0.23$, two-tailed $t$ test]. In CGP 35348, the oscillation frequency with six shocks was significantly faster than that of the control (see Fig. $7 b ; p<$

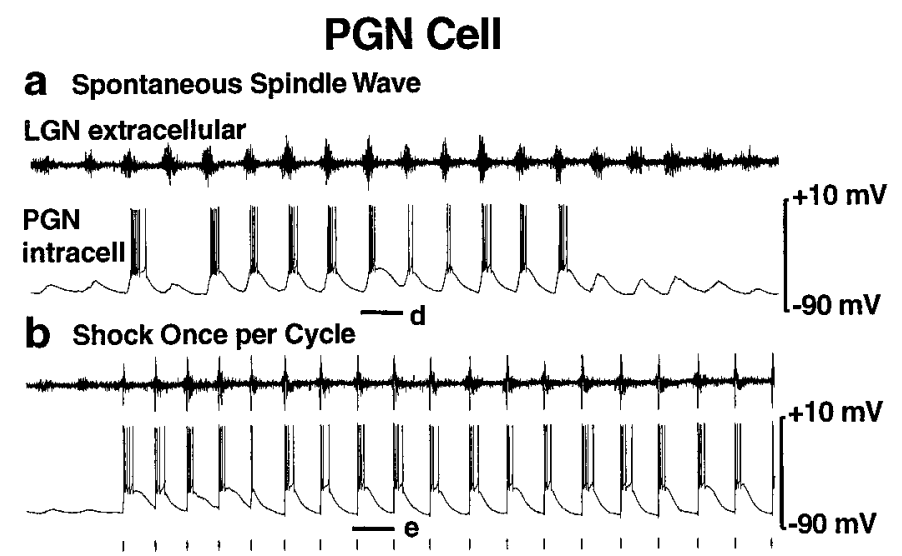

C Shock Six Times per Cycle

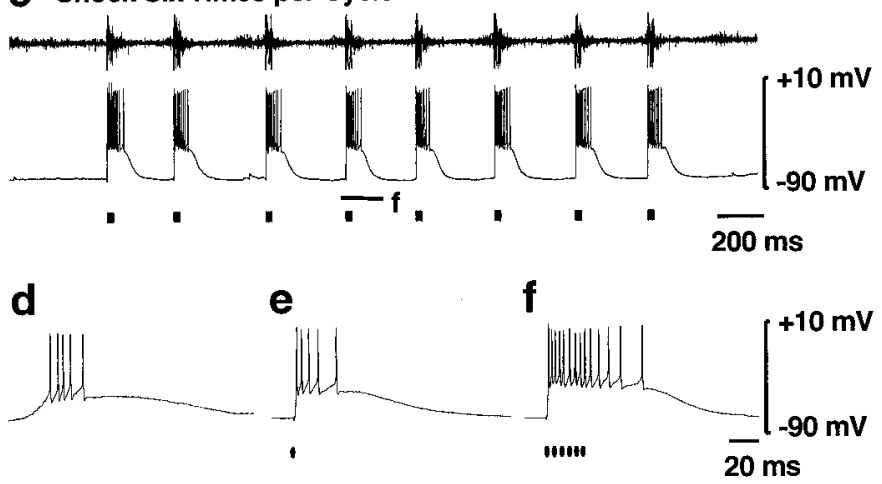

Figure 3. Single corticothalamic stimuli elicit brief PGN cell (GABAergic) bursts, whereas high-frequency bursts of six stimuli elicit sustained PGN cell burst firing. $a$, Spontaneous spindle wave (no stimulation). The LGNd extracellular recording (top trace) shows rhythmic $6-10 \mathrm{~Hz}$ burst firing. The PGN (GABAergic) cell intracellular recording (bottom trace) shows rhythmic EPSPs and $\mathrm{Ca}^{2+}$ spikes with superimposed action potential burst firing. $b$, Stimulator set to deliver one stimulus per thalamic burst. With this stimulation, spontaneous $6-10 \mathrm{~Hz}$ oscillations resembling spindle waves in both oscillation frequency and PGN cell burst firing are generated. $c$, Stimulator set to deliver a high-frequency $(200 \mathrm{~Hz})$ burst of six stimuli to the optic radiation each time it is triggered. Oscillation frequency is slower, at 3-4 Hz, with markedly increased burst firing of PGN cells. $d-f$, Expanded traces of the intracellular recordings in $a-c$ from the portions indicated by the thick horizontal lines. Note the burst firing of 3-5 action potentials in PGN cells during spontaneous spindle waves $(d)$ or with single corticothalamic stimuli $(e)$, whereas six corticothalamic stimuli elicit greatly increased bursts of 12-15 action potentials $(f)$.

0.0001), whereas spindle waves and oscillations with one shock were only slightly faster than that of the control (see Fig. $7 b ; p<$ 0.01 for both). Washout of CGP 35348 led to reversal of these effects in seven of seven experiments.

In CGP 35348 the durations of spontaneous spindle waves (3.11 $\pm 0.32 \mathrm{sec} ; n=11)$ and of oscillations with one shock per cycle $(7.10 \pm 1.78 \mathrm{sec} ; n=10)$ were similar to control conditions (see above). However, as shown in the three examples in Figure $4 d$, six shocks per cycle in the presence of CGP 35348 produced only short periods of oscillation (mean duration $=1.44 \pm 0.55$ sec; $n=10)$. These were significantly shorter than the more sustained oscillations seen under control conditions with six shocks (mean duration $=6.00 \pm 0.67 \mathrm{sec} ; n=16 ; p<0.0001$, two-tailed $t$ test). The membrane potential during six shocks per cycle had a more sustained hyperpolarization in control conditions than in the presence of CGP 35348 (Fig. $4 e ; n=8$ intracel- 


\section{Control}
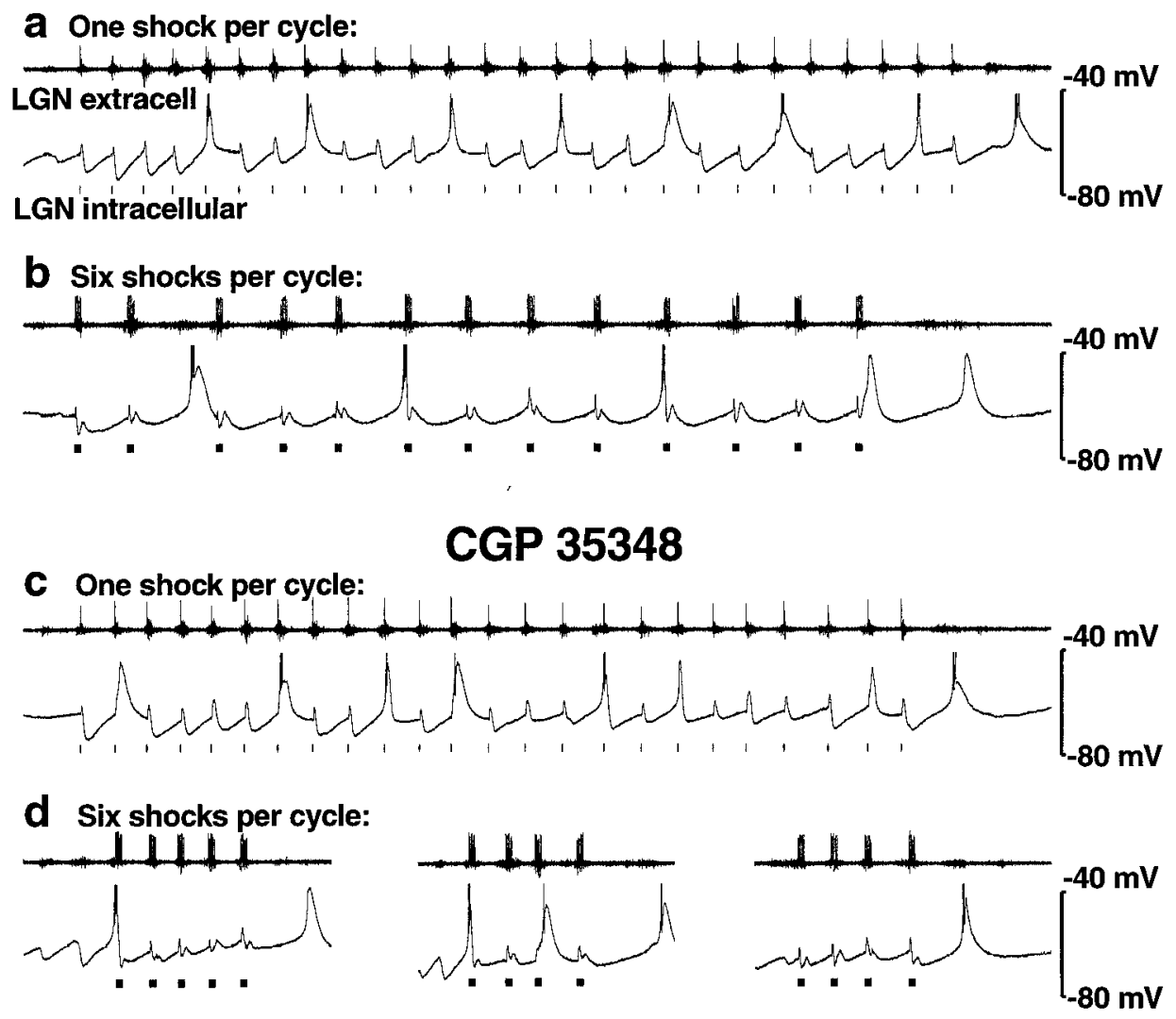

e Overlay:

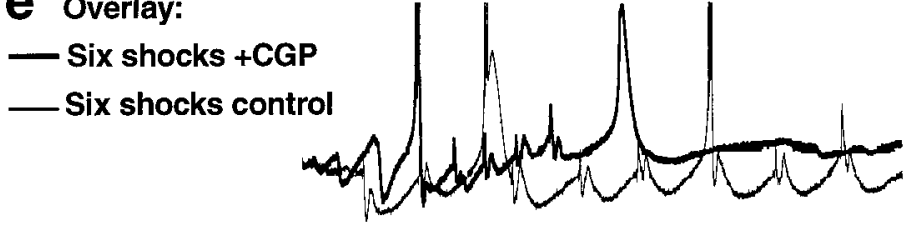

lular recordings), possibly leading to early termination of the oscillations in the presence of this $\mathrm{GABA}_{\mathrm{B}}$ receptor antagonist.

The postsynaptic potential produced by single stimuli consisted primarily of a short-duration IPSP $(158 \pm 4.2 \mathrm{msec} ; n=16)$ (Fig. $5 a$ ), presumably mediated by $\mathrm{GABA}_{\mathrm{A}}$ receptors. The postsynaptic potential produced by six stimuli was more complicated (Fig. $5 b$ ) and can best be appreciated when overlaid on the response to a single shock (Fig. 5c,f). The response to six stimuli included an early event consisting of both EPSPs and IPSPs followed by a slow IPSP lasting $\sim 300 \mathrm{msec}(307 \pm 10.9 \mathrm{msec} ; n=16)$. When $\mathrm{GABA}_{\mathrm{B}}$ receptors were blocked by CGP 35348, one stimulus per cycle still produced fast $(141 \pm 4.7 \mathrm{msec} ; n=10)$ IPSPs (Fig. $5 d)$. With six stimuli per cycle in CGP 35348 (Fig. 5e), the slow IPSP was blocked, and IPSPs had a mean duration of $152 \pm 6.5 \mathrm{msec}$ $(n=11)$, similar to that seen with single shocks or during spindle waves. Comparing the response to six shocks per cycle before and after the application of CGP 35348 revealed that the early fast IPSP-EPSP complex was preserved despite blockade of the slow IPSP (Fig. 5, compare $b, e$ ). These findings strongly suggest that bursts of corticothalamic input cause slow IPSPs and 3-4 Hz oscillations via activation of $\mathrm{GABA}_{\mathrm{B}}$ receptors.
Figure 4. $\mathrm{GABA}_{\mathrm{B}}$ receptor antagonist CGP 35348 blocks stimulus-induced 3-4 $\mathrm{Hz}$ oscillations. $a, b$, Extracellular (top traces) and intracellular (bottom traces) recordings of thalamocortical cells in control solution are shown. $a$, One corticothalamic shock per thalamic burst elicits spontaneous oscillations that resemble spindle waves, with fast (100-150 msec) IPSPs and an intrinsic frequency of $6-10 \mathrm{~Hz} . b$, At six shocks per thalamic burst, slow $(\sim 300$ $\mathrm{msec})$ IPSPs occur with an oscillation frequency of 3-4 Hz. c, Local application of CGP 35348 (2 $\mathrm{mm}$ in the puffer pipette) has no effect on the spindle wave-like $(6-10$ $\mathrm{Hz}$ ) oscillations seen with one shock per thalamic burst. $d$, However, six shocks per burst now produce spindle wave-like (6-10 $\mathrm{Hz}$ ) oscillations as well and no longer produce $3-4 \mathrm{~Hz}$ rhythms. In addition, oscillations are of shorter duration (three examples shown). Spontaneous spindle waves (like those in Fig. $2 a$ ) also continue to occur in the presence of CGP 35348 (data not shown). Action potentials are clipped at this magnification. $e$, An overlay of recordings with six shocks from control $(b)$ and CGP 35348 (d, left trace) reveals more sustained hyperpolarization under control conditions.
$\mathrm{GABA}_{\mathrm{A}}$ receptor antagonist blocks fast IPSPs and fast 6-10 Hz oscillations

What is the role of $\mathrm{GABA}_{\mathrm{A}}$ receptors in preventing $3-4 \mathrm{~Hz}$ oscillations in thalamic slices? Previously, we have reported that the block of $\mathrm{GABA}_{\mathrm{A}}$ receptors in geniculate slices results in the generation of 3-4 Hz spontaneous paroxysmal network discharges, resulting from strong bursts of activity in PGN GABAergic neurons (Bal et al., 1995a,b; Kim et al., 1997). Similarly, we found here that addition of the $\mathrm{GABA}_{\mathrm{A}}$ receptor antagonist picrotoxin (100 $\mu \mathrm{M}$ bath perfusion or $1 \mathrm{~mm}$ in the puffer pipette) resulted in $\sim 3 \mathrm{~Hz}$ oscillations whether the corticothalamic fibers were stimulated once or six times per thalamic burst (Fig. 6a,b). Fast IPSPs were blocked, and instead large slow $\sim 300 \mathrm{msec}$ IPSPs were seen, with increased rebound burst firing of thalamocortical cells regardless of the corticothalamic stimulus (Fig. 6c, $d$ ). Oscillation frequencies with one $(2.95 \pm 0.15 \mathrm{~Hz})$ or $\operatorname{six}(2.69 \pm$ $0.15 \mathrm{~Hz})$ shocks per cycle were similar $(n=6 ; p=0.24$, two-tailed $t$ test), but the oscillation frequency with one shock per cycle was significantly slower than that of control (Fig. $7 b ; p<0.0001$ ). Durations of individual oscillations in the presence of picrotoxin 


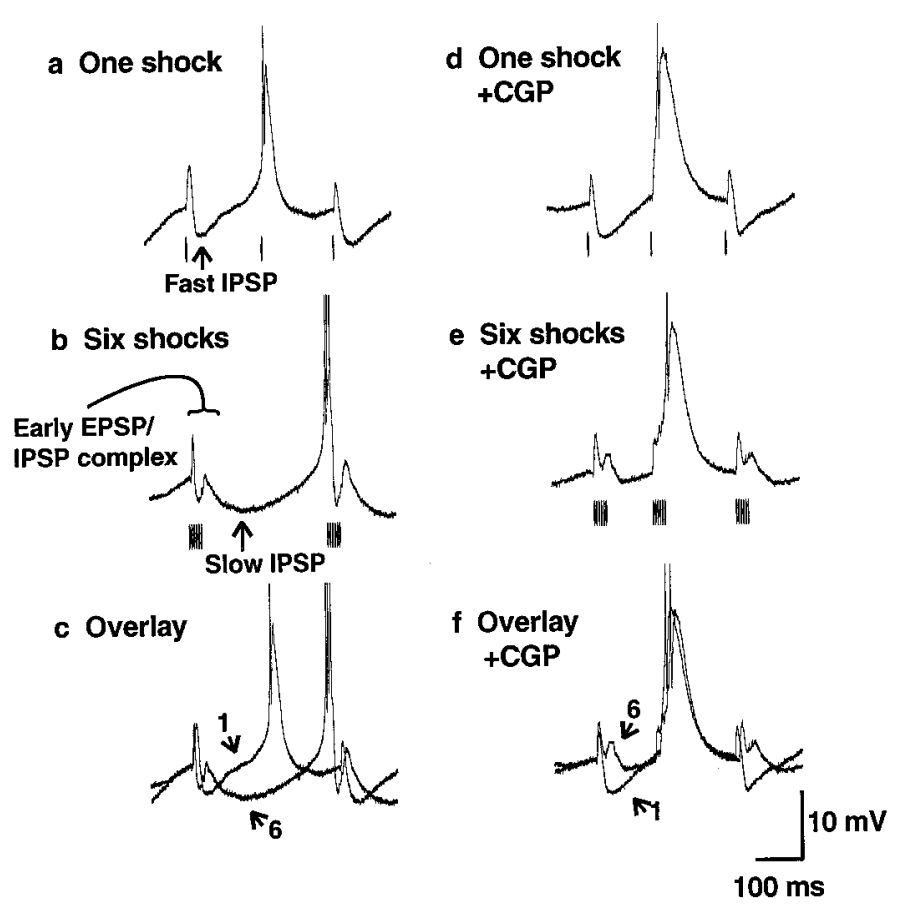

Figure 5. GABA $_{\mathrm{B}}$ receptor antagonist CGP 35348 blocks thalamocortical cell slow IPSPs. $a-c$, Intracellular recordings from a thalamocortical cell in control solution are shown. Traces from Figure 4, $a$ and $b$, are enlarged (action potentials are clipped). $a$, One corticothalamic shock per thalamic burst produces fast $(100-150 \mathrm{msec})$ IPSPs and brief rebound bursts in thalamocortical cells. $b$, Six shocks per burst produce slow $(\sim 300$ msec) IPSPs and stronger rebound burst firing. $c$, An overlay of the traces reveals that with six shocks there is an early fast IPSP-EPSP complex followed by a slow IPSP. Arrows with the numbers 1 or 6 indicate the number of shocks per burst. $d-f$, Recordings from a thalamocortical cell after local application of CGP 35348 (2 $\mathrm{mm}$ in the puffer pipette) are shown. Traces from Figure 4, $c$ and $d$, are enlarged. $d$, One shock per burst still produces fast (100-150 msec) IPSPs. $e$, However, six shocks per burst now also produce fast $(100-150 \mathrm{msec})$ spindle wave-like IPSPs. $f$, An overlay of the traces reveals that the slow IPSP is blocked, suggesting that it is mediated by $\mathrm{GABA}_{\mathrm{B}}$ receptors. However, six shocks still produce an early fast IPSP-EPSP complex.

$[6.67 \pm 0.68 \sec (n=6)$, one shock per cycle; $8.21 \pm 2.25 \sec (n=$ $6)$, six shocks per cycle] were not significantly different from control. These findings suggest that fast thalamocortical IPSPs in response to single corticothalamic stimuli, like those during spindle waves (Bal et al., 1995a,b; Kim et al., 1997; McCormick and $\mathrm{Bal}$, 1997), are mediated by $\mathrm{GABA}_{\mathrm{A}}$ receptors. In addition, $\mathrm{GABA}_{\mathrm{A}}$ receptor-mediated PGN-to-PGN cell inhibition (Huguenard and Prince, 1994; Sanchez-Vives and McCormick, 1997; Sanchez-Vives et al., 1997) may normally reduce GABAergic input to thalamocortical cells. Thus, blockade of $\mathrm{GABA}_{\mathrm{A}}$ receptors results in increased GABAergic input to thalamocortical cells, producing large $\mathrm{GABA}_{\mathrm{B}}$-mediated slow IPSPs not seen with single stimuli under control conditions.

\section{Effects of varying corticothalamic stimulation parameters}

The parameters of the corticothalamic stimulation were varied to determine which were critical to the transformation of $6-10 \mathrm{~Hz}$ spindle-like oscillations into the $3-4 \mathrm{~Hz}$ "paroxysmal" events. We varied the number of shocks in each burst $(n=6)$, the intensity of each shock $(n=7)$, the frequency of stimulation within the burst $(n=5)$, and the delay between the detected multiple unit activity in the LGNd and the stimulation of the optic radiation $(n=4)$. We found that the most important parameters were stimulus intensity and the number of stimuli in the burst. As the number of stimuli in the $200 \mathrm{~Hz}$ corticothalamic burst was increased from one to six, the spontaneous oscillation frequency gradually decreased from $6-10$ to $3-4 \mathrm{~Hz}$ (Fig. 7a). Further increases in the number of stimuli did not cause marked changes in the frequency, possibly because thalamocortical cell $\mathrm{GABA}_{\mathrm{B}}$ receptors were maximally activated. A similar relationship was found as the stimulus intensity was increased over the range of $30-200 \mu \mathrm{A}$, as long as at least two stimuli were present in the 200 $\mathrm{Hz}$ burst. Thus, low-intensity stimuli resulted in $6-10 \mathrm{~Hz}$ oscillations even if six stimuli were used, whereas higher intensity stimuli produced $3-4 \mathrm{~Hz}$ oscillations. With single stimuli, slow oscillations could not be produced unless very high $(>1 \mathrm{~mA})$ stimulus intensities were used.

Other parameters did not have dramatic effects on the oscillation frequency. The transformation to $3-4 \mathrm{~Hz}$ oscillations with six stimuli could be obtained as long as the intraburst frequency was between 40 and $300 \mathrm{~Hz}$. With intraburst frequencies below $40 \mathrm{~Hz}$, the burst of six stimuli lasted for $>125 \mathrm{msec}$, resulting in repeated and continuous feedback stimulation of the optic radiation at a frequency of $\sim 10 \mathrm{~Hz}$. As the intraburst frequency was increased above $300 \mathrm{~Hz}$, the efficiency of corticothalamic activation decreased so that oscillations at $6-10 \mathrm{~Hz}$ were evoked, resembling those seen with single stimuli. The delay in the artificial cortex circuit was varied between 0 and $50 \mathrm{msec}$ but was set at $5 \mathrm{msec}$ for most experiments. This is within the range of the fastestconducting axons between the cortex and thalamus (Swadlow and Weyand, 1987; Nowak and Bullier, 1997; Timofeev et al., 1998). Changing the delay in the artificial cortex circuit in the range of $0-50 \mathrm{msec}$ had no effect on the oscillations except to add the time of the delay itself to the oscillation cycle.

\section{DISCUSSION}

Corticothalamic interactions during sleep spindles and epileptiform activity have been studied previously in a number of systems. In vivo studies in cats and rodents have shown a large increase in rhythmic firing of both cortical and thalamic neurons during spike-wave seizures compared with spindle waves (Fisher and Prince, 1977; Kostopoulos et al., 1981; Avoli and Kostopoulos, 1982, 1983, 1990; McLachlan et al., 1984; Steriade and Contreras, 1995; Steriade et al., 1997, 1998; Kandel and Buzsaki, 1997; Danober et al., 1998). Although some studies have suggested that either the cortex (Steriade and Contreras, 1998) or thalamus (von Krosigk et al., 1993; Castro-Alamancos, 1999) alone can generate $3-4 \mathrm{~Hz}$ seizure-like activity, most evidence supports the importance of both structures interacting via reciprocal network connections in generating this abnormal rhythm (Avoli and Kostopoulos, 1982, 1990; Gloor et al., 1990; Danober et al., 1998). Topical application of the $\mathrm{GABA}_{\mathrm{A}}$ antagonists penicillin or bicuculline to the cortex, but not the thalamus, is sufficient to convert the corticothalamic network from spindle waves to 3-4 Hz spike-wave seizures (Avoli and Gloor, 1982; Avoli and Kostopoulos, 1982; Steriade and Contreras, 1998). This suggests that abnormally increased cortical firing is capable of switching the network from normal spindle waves to spike-wave seizures. How could increased firing of cortical neurons produce this transition?

Corticothalamic fibers form excitatory synapses in the thalamus on both thalamocortical neurons and GABAergic reticular thalamic cells (PGN cells in the LGN region), as well as local interneurons. The discharge of brief bursts of action potentials in 

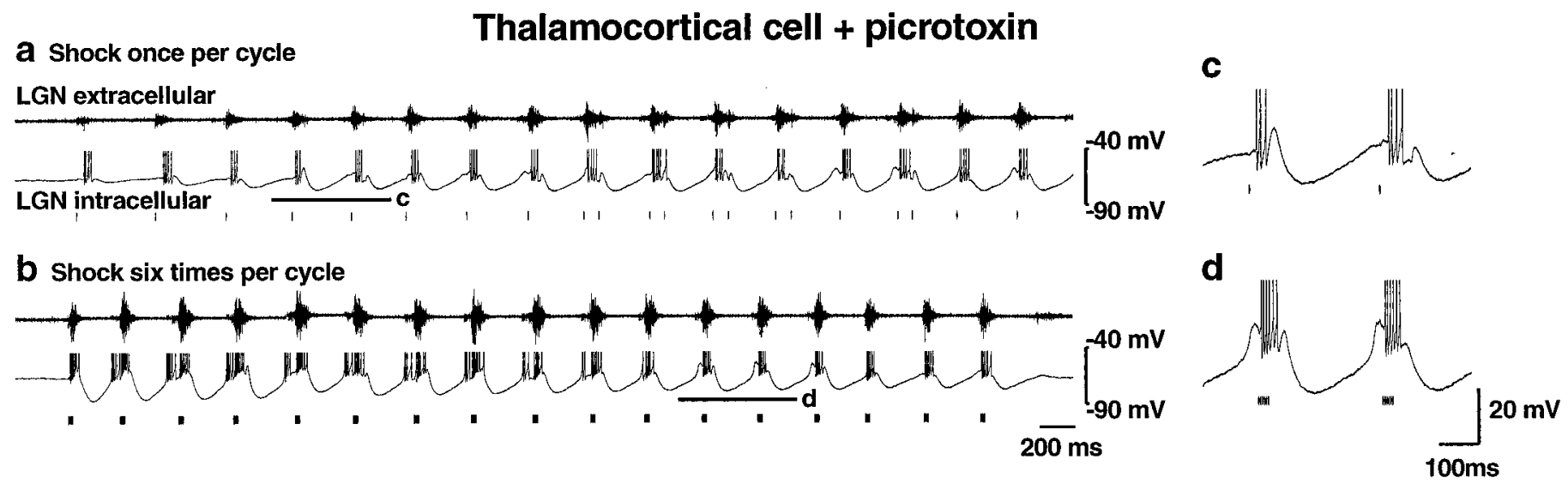

Figure 6. The GABA receptor antagonist picrotoxin blocks $6-10 \mathrm{~Hz}$ oscillations and fast IPSPs. $a$, $b$, Thalamocortical cell intracellular (bottom traces) and extracellular (top traces) recordings in the presence of picrotoxin (100 $\mu \mathrm{M}$ in bath perfusion). Either one $(a)$ or six $(b)$ corticothalamic shocks per thalamic burst elicit slow $(\sim 300 \mathrm{msec})$ IPSPs with large rebound bursts (action potentials are clipped at this magnification) and spontaneous 3-4 Hz oscillations. Under control conditions, this thalamic slice and thalamocortical cell exhibited $6-10 \mathrm{~Hz}$ oscillations with one shock per burst and 3-4 $\mathrm{Hz}$ oscillations with six shocks per burst (data not shown). $c, d$, Expanded traces from segments indicated by the thick horizontal lines in $a(c)$ and $b(d)$.

PGN neurons produces fast (100-150 msec) IPSPs mediated by $\mathrm{GABA}_{\mathrm{A}}$ receptors, whereas the firing of sustained bursts in PGN cells elicits, in addition to GABA $_{\mathrm{A}}$ IPSPs, slow ( $\left.\sim 300 \mathrm{msec}\right)$ $\mathrm{GABA}_{\mathrm{B}}$ receptor-mediated IPSPs in thalamocortical cells (Kim et al., 1997). We have shown here that increased firing in the corticothalamic pathway may be able to transform PGN cell discharge from brief to sustained bursts of action potentials (see also Blumenfeld and McCormick, 1999; Debay et al., 1999), as is seen in these cells in the transition from spindles to spike-wave seizures (Neckelmann et al., 1998; Timofeev et al., 1998). This transition is accompanied by a change in thalamocortical cell IPSPs from fast to slow and in spontaneous oscillations from spindle waves to $3-4 \mathrm{~Hz}$ seizure-like events. It is possible, or even likely, that our electrical stimulation of the optic radiation also antidromically activated thalamocortical cells and thus activated PGN cells via collaterals of these axons. However, antidromic action potentials were only rarely observed with intracellular recordings of thalamocortical cells, suggesting that this was not the dominant mechanism by which PGN cells were activated by this stimulation. Interestingly, previous in vivo studies have demonstrated antidromic activation of thalamocortical axons during seizure generation (Noebels and Prince, 1978; Pinault and $\mathrm{Pu}-$ main, 1989), suggesting that this mechanism may contribute to these pathological events.

What effects does increased corticothalamic firing have on the thalamocortical network, and how does this cause a transformation to slow 3-4 Hz paroxysmal activity? There are several possible mechanisms that may contribute to this transition. As shown here, increased corticothalamic firing may produce increased burst firing of GABAergic PGN neurons resulting in slow $\sim 300$ msec GABA $_{\mathrm{B}}$-mediated IPSPs in thalamocortical cells. These slow IPSPs are particularly effective in removing inactivation of the low-threshold $\mathrm{Ca}^{2+}$ current and therefore in generating large, delayed rebound bursts of action potentials that initiate the next cycle of the oscillation. Thus, activation of $\sim 300 \mathrm{msec}$ $\mathrm{GABA}_{\mathrm{B}}$-mediated IPSPs may be critical to setting the oscillation frequency of spike-wave seizure. However, in addition to the $\mathrm{GABA}_{\mathrm{B}}$-mediated slow IPSP in thalamocortical cells, burst firing in corticothalamic inputs may also activate several other synaptic changes in the thalamocortical network. Previous work (Kim and
McCormick, 1998; von Krosigk et al., 1999) has shown a decrement in $\mathrm{GABA}_{\mathrm{A}}$-mediated fast IPSPs with repeated firing of presynaptic GABAergic neurons. This may be caused by postsynaptic $\mathrm{GABA}_{\mathrm{A}}$ receptor desensitization or presynaptic $\mathrm{GABA}_{\mathrm{B}}$ receptor-mediated autoinhibition (Thompson et al., 1993; Wu and Saggau, 1995). In addition, repetitive firing in the corticothalamic pathway causes facilitation of EPSPs in thalamocortical cells (Deschênes and Hu, 1990; von Krosigk et al., 1999). One could postulate that these two effects of corticothalamic burst firing (decrement of fast IPSPs, and enhancement of EPSPs) alter the early phase of the thalamocortical cell response so that a prominent early hyperpolarization is no longer present, thus preventing early rebound bursts and promoting slow oscillations (Fig. $5 a-c$ ). However, the change in shape of the early phase of the thalamocortical cell response alone is not sufficient to produce delayed rebound bursts and $3-4 \mathrm{~Hz}$ oscillations (Fig. $5 d-f$ ). Thus, when the slow IPSP was blocked with the GABA $_{\mathrm{B}}$ antagonist CGP 35348, early rebound bursts returned (Fig. 5e), and a reversion to $6-10 \mathrm{~Hz}$ oscillations was seen. These findings suggest that enhanced activation of $\mathrm{GABA}_{\mathrm{B}}$ receptors in thalamocortical cells in response to increased corticothalamic inputs may be critical to setting the oscillation frequency during spike-wave seizures at 3-4 Hz (Hosford et al., 1992; Castro-Alamancos, 1999).

Why are sustained bursts required in GABAergic PGN cells to activate $\mathrm{GABA}_{\mathrm{B}}$ receptors in thalamocortical cells? Previous work with hippocampal (Sodickson and Bean, 1996), cortical (Thomson and Destexhe, 1999), and thalamic (Kim et al., 1997; Kim and McCormick, 1998) neurons has shown that $\mathrm{GABA}_{\mathrm{B}}$ receptor-mediated IPSPs activate relatively slowly, possibly because of the kinetics of G-protein-mediated receptor-channel interactions (Destexhe and Sejnowski, 1995; Thomson and Destexhe, 1999). In addition it has been proposed that $\mathrm{GABA}_{\mathrm{B}}$ receptors may be located extrasynaptically and could, therefore, require more presynaptic GABA release for spillover to the $\mathrm{GABA}_{\mathrm{B}}$ receptor sites to occur (Mody et al., 1994). Differential activation of $\mathrm{GABA}_{\mathrm{A}}$ and $\mathrm{GABA}_{\mathrm{B}}$ receptors by different activity patterns may explain why $\mathrm{GABA}_{\mathrm{A}}$ agonists such as clonazepam reduce absence seizures (Huguenard and Prince, 1994; Huguenard, 1999), whereas agents such as the GABA transaminase 


\section{a Control}
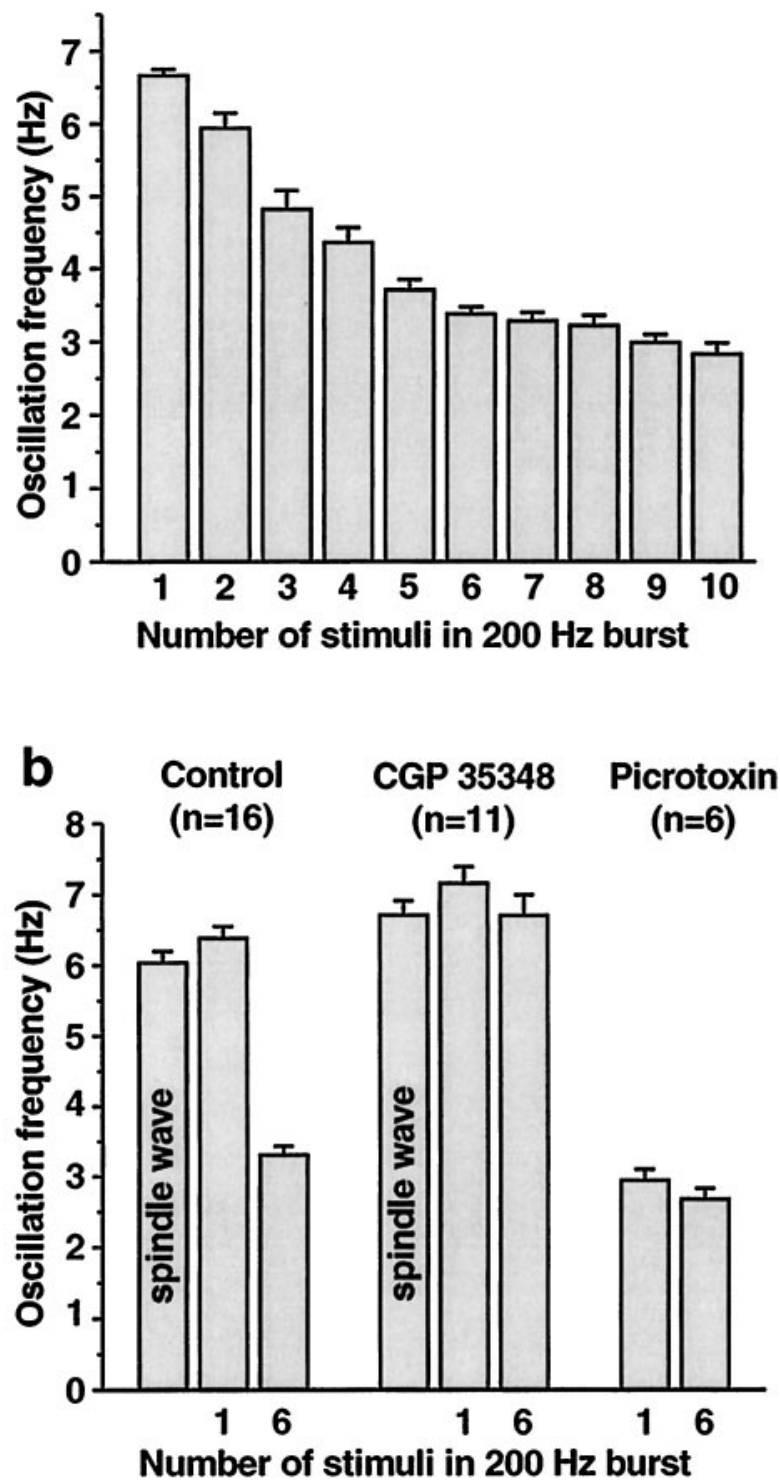

Figure 7. Summary of effects of corticothalamic burst intensity and $\mathrm{GABA}_{\mathrm{A}}$ and $\mathrm{GABA}_{\mathrm{B}}$ antagonists. $a$, One corticothalamic stimulus per thalamic burst produces spontaneous $6-7 \mathrm{~Hz}$ spindle wave-like oscillations (leftmost bar in histogram). As the number of stimuli in the $200 \mathrm{~Hz}$ burst is increased, the oscillation frequency gradually slows until it reaches $3-4 \mathrm{~Hz}$ at six stimuli per burst. Further increases in the number of stimuli do not produce large changes in oscillation frequency, possibly because $\mathrm{GABA}_{\mathrm{B}}$ receptors are maximally activated. Data are from the cell illustrated in Figures 4 and 5. The numbers of interstimulus intervals averaged to calculate oscillation frequencies for 1 through 10 stimuli were $54,19,21$, $18,26,47,22,13,16$, and 14 , respectively. $b$, Effects of the $\mathrm{GABA}_{\mathrm{B}}$ antagonist CGP 35348 and the GABA $_{\mathrm{A}}$ antagonist picrotoxin on network oscillation frequency are shown. In control conditions, the oscillation frequency is $6-7 \mathrm{~Hz}$ in spontaneous spindle waves (no stimuli) and with one stimulus per cycle, whereas it is $\sim 3 \mathrm{~Hz}$ when bursts of six stimuli are used. In the presence of CGP 35348, the oscillation frequency remains at $6-7 \mathrm{~Hz}$ whether one or six stimuli are given. In picrotoxin, the oscillation frequency is $\sim 3 \mathrm{~Hz}$ regardless of whether one or six stimuli are given. Group frequency data are shown from 13 intracellular and 3 extracellular recordings in which one or both drugs were applied. Mean and SEM values for all frequencies are listed in Results. The following frequency changes were significant at the $p<0.0001$ level (two-tailed $t$ test): control one stimulus versus control six stimuli, control six stimuli versus CGP 35348 six stimuli, and control one stimulus versus picrotoxin one stimulus. inhibitor vigabatrin that causes a generalized increase in brain GABA levels can exacerbate absence seizures (Guberman, 1996).

One widely used model of absence seizures is the generation of spike-wave attacks in rats, particularly in the WAG/Rij or genetic absence epilepsy rats from Strasbourg strains (Buzsaki et al., 1988; Coenen et al., 1992; Marescaux et al., 1992; Vergnes and Marescaux, 1992). Although these seizures depend on the interaction of the thalamus and cerebral cortex and are blocked by lesions of the thalamic reticular nucleus, the precise role for $\mathrm{GABA}_{\mathrm{B}}$ receptors is unclear, because the frequency of these spike-wave seizures is in the range of $6-8 \mathrm{~Hz}$ (Pinault et al., 1998). Computational models suggest that $\mathrm{GABA}_{\mathrm{B}}$ receptors may facilitate spike-wave seizure activity in rodents by activating a relatively sustained hyperpolarization of the membrane potential, which enhances the ability of fast $\mathrm{GABA}_{\mathrm{A}}$ IPSPs to generate rebound $\mathrm{Ca}^{2+}$ spikes and action potentials (Destexhe et al., 1999). In any case, the interaction of the cerebral cortex and thalamus and, particularly, the activation of strong GABAergic IPSPs in thalamocortical neurons appear to be critically important in the generation of several forms of spike-wave seizures.

The recording arrangement used for our present studies has several advantages not present in other preparations. The artificial cortex circuit allows a variety of cortical input and output parameters to be studied. Use of sagittal slices of the ferret LGN preserves the intrinsic thalamic circuitry needed to generate spontaneous oscillations (Bal et al., 1995a,b). The 3-4 Hz oscillations that we observed with this circuit resemble those seen in absence seizures (Kellaway, 1985; Engel and Pedley, 1999) in that they were often initiated by a spindle wave and the frequency was slightly higher at the beginning than at the end of each oscillation.

The mechanism for the slowing of oscillation frequency during the course of each event remains unknown and warrants further investigation. Interestingly, spontaneous spindle waves had a slightly shorter duration than did oscillations elicited with one shock per cycle. The small afterdepolarization seen after spindle waves because of persistent activation of the hyperpolarizationactivated cation current $I_{h}$ (Bal and McCormick, 1996) was also present with one shock per cycle. Thus, one could speculate that optic radiation stimulation enhances spindle waves, requiring larger increases in $I_{h}$ for the spindle waves to stop. Another phenomenon for which the mechanism is presently unknown is the shorter duration of oscillations produced by bursts of six shocks in the presence of CGP 35348 (Fig. 4d,e). Close examination of the membrane potential traces revealed that after the block of $\mathrm{GABA}_{\mathrm{B}}$ receptors the membrane potential did not hyperpolarize as much as in the control, during the generation of rhythmic network oscillations. Thus, the activation of $\mathrm{GABA}_{\mathrm{B}}$ receptors may facilitate the maintained hyperpolarization of thalamocortical cells, prolonging the network oscillations.

Our findings provide an important example of the dynamic state of interactions between the cerebral cortex and thalamus. The generation of both normal and abnormal patterns of activity depend on the status of local as well as global network interactions. In the case of abnormal paroxysmal oscillations, primary deficits at any of a number of locations may result in a relatively similar pattern of activity. For example, disinhibition of thalamic reticular neurons from one and another (von Krosigk et al., 1993; Sanchez-Vives and McCormick, 1997; Sanchez-Vives et al., 1997; Huntsman et al., 1999), generation of low-threshold $\mathrm{Ca}^{2+}$ spikes in thalamic reticular neurons that are larger than usual (Tsakiridou et al., 1995), overly strong activation of $\mathrm{GABA}_{\mathrm{B}}$ receptors on thalamocortical neurons (von Krosigk et al., 1993), or, as sup- 
ported by the present study, abnormally strong responses of cortical networks to thalamic volleys may all lead to the perversion of thalamocortical networks into the generation of abnormal rhythms. The findings reported here demonstrate how increased activity in one portion of a network may, via differential effects on neurotransmitter systems and appropriate feedback, transform the global activity pattern of the entire network. Understanding the mechanisms for switching network activity patterns may be essential for explaining the transitions occurring during normal states of sleep and arousal, as well as the generation of seizures, tremors, and possibly a wide variety of other neurological disorders.

\section{REFERENCES}

Aghajanian GK, Rasmussen K (1989) Intracellular studies in the facial nucleus illustrating a simple new method for obtaining viable motoneurons in adult rat brain slices. Synapse 3:331-338.

Avoli M, Gloor P (1982) Interaction of cortex and thalamus in spike and wave discharges of feline generalized penicillin epilepsy. Exp Neurol 76:196-217.

Avoli M, Kostopoulos G (1982) Participation of corticothalamic cells in penicillin-induced generalized spike and wave discharges. Brain Res 247:159-163.

Avoli M, Gloor P, Kostopoulos G, Gotman J (1983) An analysis of penicillin-induced generalized spike and wave discharge using simultaneous recordings of cortical and thalamic single neurons. J Neurophysiol 50:819-837.

Avoli M, Gloor P, Kostopoulos G, Naquet R (eds) (1990) Generalized epilepsy. Neurobiological approaches. Boston: Birkhauser.

Bal T, McCormick DA (1996) What stops synchronized thalamocortical oscillations? Neuron 17:297-308.

Bal T, von Krosigk M, McCormick DA (1995a) Synaptic and membrane mechanisms underlying synchronized oscillations in the ferret LGNd in vitro. J Physiol (Lond) 483:641-663.

Bal T, von Krosigk M, McCormick DA (1995b) Role of the ferret perigeniculate nucleus in the generation of synchronized oscillations in vitro. J Physiol (Lond) 483:665-685.

Blumenfeld H, McCormick DA (1999) Abnormal cortical burst firing may cause spike-and-wave seizures through thalamic $\mathrm{GABA}_{\mathrm{B}}$ receptors. Soc Neurosci Abstr 25:539.

Buzsaki G, Bickford RG, Ponomareff G, Thal LJ, Mandel R, Gage FH (1988) Nucleus basalis and thalamic control of neocortical activity in the freely moving rat. J Neurosci 8:4007-4026.

Castro-Alamancos MA (1999) Neocortical synchronized oscillations induced by thalamic disinhibition in vivo. J Neurosci 19(RC27):1-7.

Coenen AM, Drinkenberg WH, Inoue M, van Luijtelaar EL (1992) Genetic models of absence epilepsy, with emphasis on the WAG/Rij strain of rats. Epilepsy Res 12:75-86.

Danober L, Deransart C, Depaulis A, Vergnes M, Marescaux C (1998) Pathophysiological mechanisms of genetic absence epilepsy in the rat. Prog Neurobiol 55:27-57.

Debay D, Destexhe A, Grant K, Bal T (1999) Corticothalamic feedback can force intact thalamic circuits into paroxysmal oscillations at $3 \mathrm{~Hz}$. Soc Neurosci Abstr 25:1167.

Deschênes M, Hu B (1990) Electrophysiology and pharmacology of the corticothalamic input to lateral thalamic nuclei: an intracellular study in the cat. Eur J Neurosci 2:140-152.

Destexhe A (1998) Spike-and-wave oscillations based on the properties of GABAB receptors. J Neurosci 18:9099-9111.

Destexhe A (1999) Can GABA $A$ conductances explain the fast oscillation frequency of absence seizures in rodents? Eur $\mathrm{J}$ Neurosci 6:2175-2181.

Destexhe A, Sejnowski TJ (1995) G-protein activation kinetics and spillover of gamma-aminobutyric acid may account for differences between inhibitory responses in the hippocampus and thalamus. Proc Natl Acad Sci USA 92:9515-9519.

Destexhe A, McCormick DA, Sejnowski TJ (1999) Thalamic and thalamocortical mechanisms underlying $3 \mathrm{~Hz}$ spike-and-wave discharges. Prog Brain Res 121:289-307.

Engel J, Pedley TA (eds) (1999) Epilepsy: a comprehensive textbook. Baltimore: Lippincott Williams \& Wilkins.

Fisher RS, Prince DA (1977) Spike-wave rhythms in cat cortex induced by parenteral penicillin. II. Cellular features. Electroencephalogr Clin Neurophysiol 42:625-639.

Gloor P, Avoli M, Kostopoulos G (1990) Thalamocortical relationships in generalized epilepsy with bilaterally synchronous spike-andwavedischarge. In: Generalized epilepsy. Neurobiological approaches (Avoli M, Gloor P, Kostopoulos G, Naquet R, eds), pp 190-212. Boston: Birkhauser.

Guberman A (1996) Vigabatrin. Can J Neurol Sci 23:S13-S17.

Hosford DA, Clark S, Cao Z, Wilson WA, Lin F-H, Morisett RA, Huin A (1992) The role of GABA-B receptor activation in absence seizures of lethargic (lh/lh) mice. Science 257:398-401.

Huguenard JR (1999) Neuronal circuitry of thalamocortical epilepsy and mechanisms of antiabsence drug action. Adv Neurol 79:991-999.

Huguenard JR, Prince DA (1994) Clonazepam suppresses GABA $_{\mathrm{B}^{-}}$ mediated inhibition in thalamic relay neurons through effects in nucleus reticularis. J Neurophysiol 71:2576-2581.

Huntsman MM, Porcello DM, Homanics GE, DeLorey TM, Huguenard JR (1999) Reciprocal inhibitory connections and network synchrony in the mammalian thalamus. Science 283:541-543.

Kandel A, Buzsaki G (1997) Cellular-synaptic generation of sleep spindles, spike-and-wave discharges, and evoked thalamocortical responses in the neocortex of the rat. J Neurosci 17:6783-6797.

Kellaway P (1985) Sleep and epilepsy. Epilepsia 26:S15-S30.

Kim U, McCormick DA (1998) The functional influence of burst and tonic firing mode on synaptic interactions in the thalamus. J Neurosci 18:9500-9516.

Kim U, Sanchez-Vives MV, McCormick DA (1997) Functional dynamics of GABAergic inhibition in the thalamus. Science 278:130-134.

Kostopoulos G, Gloor P, Pellegrini A, Gotman J (1981) A study of the transition from spindles to spike and wave discharge in feline generalized penicillin epilepsy: microphysiological features. Exp Neurol 73:55-77.

Marescaux C, Vergnes M, Depaulis A (1992) Genetic absence epilepsy in rats from Strasbourg-a review. J Neural Transm Suppl 35:37-69.

McCormick DA, Bal T (1997) Sleep and arousal: thalamocortical mechanisms. Annu Rev Neurosci 20:185-215.

McLachlan RS, Avoli M, Gloor P (1984) Transition from spindles to generalized spike and wave discharges in the cat: simultaneous singlecell recordings in cortex and thalamus. Exp Neurol 85:413-425.

Mody I, De Koninck Y, Otis TS, Soltesz I (1994) Bridging the cleft at GABA synapses in the brain. Trends Neurosci 17:517-525.

Neckelmann D, Amzica F, Steriade M (1998) Spike-wave complexes and fast components of cortically generated seizures. III. Synchronizing mechanisms. J Neurophysiol 80:1480-1494.

Niedermeyer E (1990) The epilepsies. Diagnosis and management. Baltimore: Urban and Schwarzenberg.

Niedermeyer E (1993) Sleep and EEG. In: Electroencephalograph. Basic principles, clinical applications, and related fields, 3rd Edition (Niedermeyer E, Lopes Da Silva F, eds), pp 153-166. Baltimore: Williams \& Wilkins.

Noebels J, Prince DA (1978) Development of focal seizures in cerebral cortex: role of axon terminal bursting. J Neurophysiol 41:1267-1281.

Nowak LG, Bullier J (1997) The timing of information transfer in the visual system, Vol 12, Cerebral cortex (Rockland KS, Kaas JH, Peters A, eds), pp 205-241. New York: Plenum.

Pinault D, Pumain R (1989) Antidromic firing occurs spontaneously on thalamic relay neurons: triggering of somatic intrinsic burst discharges by ectopic action potentials. Neuroscience 31:625-637.

Pinault D, Leresche N, Charpier S, Deniau JM, Marescaux C, Vergnes M, Crunelli V (1998) Intracellular recordings in thalamic neurones during spontaneous spike and wave discharges in rats with absence epilepsy. J Physiol (Lond ) 509:449-456.

Sanchez-Vives MV, McCormick DA (1997) Functional properties of perigeniculate inhibition of LGNd thalamocortical neurons in vitro. J Neurosci 17:8880-8893.

Sanchez-Vives MV, Bal T, McCormick DA (1997) Inhibitory interactions between perigeniculate GABAergic neurons. J Neurosci 17:8894-8908.

Sodickson DL, Bean BP (1996) GABA $_{B}$ receptor-activated inwardly rectifying potassium current in dissociated hippocampal CA3 neurons. J Neurosci 16:6374-6385.

Steriade M, Contreras D (1995) Relations between cortical and thalamic cellular events during transition from sleep patterns to paroxysmal activity. J Neurosci 15:623-642.

Steriade M, Contreras D (1998) Spike-wave complexes and fast compo- 
nents of cortically generated seizures. I. Role of neocortex and thalamus. J Neurophysiol 80:1439-1455.

Steriade M, McCormick DA, Sejnowski TJ (1993) Thalamocortical oscillations in the sleeping and aroused brain. Science 262:679-685.

Steriade M, Jones EG, McCormick DA (1997) Thalamus, Vol 1, Organization and function. New York: Elsevier.

Steriade M, Amzica F, Neckelmann D, Timofeev I (1998) Spike-wave complexes and fast components of cortically generated seizures. II. Extra- and intracellular patterns. J Neurophysiol 80:1456-1479.

Swadlow HA, Weyand TG (1987) Corticogeniculate neurons, corticotectal neurons, and suspected interneurons in visual cortex of awake rabbits: receptive-field properties, axonal properties, and effects of EEG arousal. J Neurophysiol 57:977-1001.

Thompson SM, Capogna M, Sanziani M (1993) Presynaptic inhibition in the hippocampus. Trends Neurosci 16:222-227.

Thomson AM, Destexhe A (1999) Dual intracellular recordings and computational models of slow inhibitory postsynaptic potentials in rat neocortical and hippocampal slices. Neuroscience 92:1193-1215.

Timofeev I, Grenier F, Steriade M (1998) Spike-wave complexes and fast components of cortically generated seizures. IV. Paroxysmal fast runs in cortical and thalamic neurons. J Neurophysiol 80:1495-1513.

Tsakiridou E, Bertollini L, de Curtis M, Avanzini G, Pape HC (1995) Selective increase in T-type calcium conductance of reticular thalamic neurons in a rat model of absence epilepsy. J Neurosci 15:3110-3117. van Brederode JF, Snyder GL (1992) A comparison of the electrophysiological properties of morphologically identified cells in layers $5 \mathrm{~B}$ and 6 of the rat neocortex. Neuroscience 50:315-337.

Vergnes M, Marescaux C (1992) Cortical and thalamic lesions in rats with genetic absence epilepsy. J Neural Transm Suppl 35:71-83.

von Krosigk M, Bal T, McCormick DA (1993) Cellular mechanisms of a synchronized oscillation in the thalamus. Science 261:361-364.

von Krosigk M, Monckton J, Reiner P, McCormick DA (1999) Dynamic properties of corticothalamic EPSPs and thalamic reticular IPSPs in thalamocortical neurons of the guinea pig dorsal lateral geniculate nucleus. Neuroscience 91:7-20.

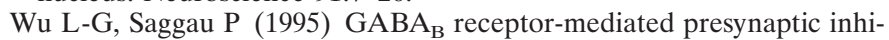
bition in guinea-pig hippocampus is caused by reduction of presynaptic $\mathrm{Ca}^{2+}$ influx. J Physiol (Lond) 485:649-657. 